\title{
The Need for Conservation in the Sea
}

\author{
By Eugenie Clark
}

Over-fishing is a serious threat to many species of fish, whether commercial or for sport, and destruction of habitat is not confined to the land: in the Caribbean whole coral reefs may be destroyed by the anchors of sight-seeing boats. Dr. Clark, Director of the Cape Haze Marine Laboratory at Sarasota, Florida, urges the establishment of more underwater sanctuaries for marine life.

A $\mathbf{T}$ the first World Conference on National Parks in Seattle in A 1962, there was a call for the establishment of marine parks which would be sanctuaries for marine life. In 1963, at the 16th International Conference of Zoology in Washington Dr. Luc Hoffman presented a fine paper on wetlands, the areas adjacent to the sea. These are very important in considering any conservation measures to be taken on the sea, because our coastal waters are strongly dependent on what we do to the land adjacent to the sea. At this symposium Carlton Ray, one of the leading sponsors in this country of marine parks and conservation of our coastal seas, also stressed the great need to consider not only the sea but the adjacent land areas.

The largest animal that ever lived, the blue whale, is faced with possible extinction. With modern methods for capturing whalesfactory ships, explosive heads on harpoons, and helicopters for spotting-the whale populations of the seas are being drastically reduced. The International Whaling Commission has been effective in getting through many regulations, but it is still not recognised by some countries, and others do not observe the quotas allotted. More than 630,000 fin whales have been flilled in this century alone, the blue, the humpback, and the sei whale populations have been greatly reduced, and all the large whales are threatened with extinction. For 1966-67 the International Whaling Commission set a quota of 3,500 blue whale units as compared with 14,500 units set 10 years ago, which shows that the Commission is very much aware of the gradual reduction of the large whale populations in the world.

New fishing methods are causing great concern to many people who love the sea-sport fishermen, scientific collectors, skin divers, and SCUBA divers. Without control, the long-line fishing can become terribly destructive and perhaps threaten the extinction of some of the big-game fish, at least in some areas. Statistics from Japanese commercial fishermen, who are the most active in the world today, show that in 1966 they took enormous numbers of big game fish, including 459,000 blue marlin. In 1965 they took 446,000 striped marlin, 45,000 black marlin, 269,000 sword fish, 226,000 sail fish, 
along with tuna, which are the main object of the long-line fishing. The tuna catches, for which statistics are not available, must be huge.

With our international waters coming as close as 12 miles along the shore line, the long-lines of Japanese and Russian fishermen can be set outside the limit yet close enough to threaten the fish populations in the territorial waters of countries that take great pride in their big game fish. Peru and Chile, harassed by the problem of foreign commercial fishermen, have agreed with some other countries to extend their territorial waters out to 200 miles from shore. This extension is not recognised by other countries yet, but most people who are concerned with the sea feel that the 12-mile limit is not enough, and the countries of the world should really own and control the adjacent continental shelf. In the littoral zone greater conservation measures can be taken. Skin divers, SCUBA divers, and people who are working and experimenting in shallow waters, are particularly aware of the destruction that is going on along the bed of our coastal waters.

The divers themselves have been responsible for some of this destruction. Amateur divers are enthusiastic collectors of sea-fans and pieces of coral, and find it hard to resist spearing fish, even the slow inedible varieties, though after a while this wears off. The experienced skin-divers, who have a more serious interest in the sea and really love diving and seeing all the marvels and beauty of the underwater world, understand the terrible waste and destruction of continually killing or removing marine organisms from the shallow seas. The American Littoral Society, in which there are many skin divers, concerned about destruction in waters along the shore, are trying hard to promote conservation programmes, develop artificial reefs, and save wrecks that are not hazards to navigation and which form unintended but effective artificial reefs.

\section{The Marine Park}

One of the most effective ways to protect the littoral marine life is the development of marine parks, either state or government controlled. Othello Wallis in the US Department of the Interior endorses this method of conservation. Unfortunately, recent surveys by the National Park Service have shown that there are pitifully few suitable areas left along our coasts that would make good marine parks.

Among our government-controlled marine parks there are several I would like to mention. Buck Island, which is near St. Croix in the American Virgin Islands, was recently declared a national park with full protection of its marine life. The national park at Key Largo called "Penny Camp" prohibits skin divers from shooting fish, but allows commercial fishermen to take fish. This is not the way a national park should be operated. Recently an underwater sanctuary was established in the Palau Islands in Micronesia, which is a United States Trust Territory, and Dr. Jack Randall of the Bishop Museum 
has been trying very hard to get other underwater parks established in the Pacific and the Atlantic. Attempts are in progress to make a marine park in Hawaii near the Oceanographic Institute and Sea Life Park.

Here in California there is now a proposal to establish an underwater park at La Jolla, adjacent to the Institute of Oceanography, and many are hoping that such a marine park could be extended up the coast to include the area off the Torrey Pines State Park. This is one of the best places to establish an underwater park, in connection with the National Park System; the existing park could be extended into the water, thus giving a natural underwater park contiguous with the existing national park.

The film that I have to show you was made by Dr. John E. Randall, and his assistant, Robert E. Shroder, to show the varied and wonderful marine life at Buck Island, off St. Croix in the Virgin Islands, as part of a survey for the National Park Service. Dr. Randall felt that this island was one of the most suitable for a national park. It is about a mile long, with a barrier reef around it, instead of the fringing reef found on most of the other Virgin Islands. The lagoon between the island and the coral reef makes an exceptionally interesting and safe place for people to dive and observe underwater life. It was as a result of this survey that President Kennedy, on December 29, 1961, proclaimed Buck Island a National Monument.

Like many of the islands in the Carribean close to cities with airports, Buck Island is frequently visited by sightseers, including skin divers. Unfortunately such visitors often do not realise that picking just one piece of coral, multiplied by the hundreds of thousands of visitors, can cause great destruction to coral reefs. Also each time a boat is anchored, if the anchor is put on a reef it will tear off some of the coral. Jim Brown, who operates a skin divers' guide service in Puerto Rico, tells me that one of the beautiful coral reefs there has been destroyed by the anchors of sightseeing boats.

In the protected shallow lagoon within the barrier reef at Buck Island there are many smaller corals, and, now that the fish life is protected, divers can get a close look at the natural habitat of the coral area. When you spear fish, not only are you destroying some of the fish in the area, but you make other fish wary of divers. Many fish soon leave the area, and those that stay do not allow divers to get close.

The rich marine life at Buck Island is now protected. Efforts to establish other marine parks all over populated coasts of the world should be encouraged and supported at the national level. Conservation of marine animals in deeper waters, especially the heavily fished schooling fishes and whales, should be more effectively controlled at an international level. 